\title{
The Mediating Role of Organizational Excellence Between Total Quality Management Practices and Sustainability:
}

\section{A Preliminary}

\author{
Muslim Diekola Akanmu ${ }^{1, *}$ Bahtiar Mohamad $^{2}$ \\ ${ }^{1}$ School of Technology Management and Logistic (STML), Universiti Utara Malaysia, Malaysia \\ ${ }^{2}$ Othman Yeop Abdullah Graduate School of Business (OYAGSB), Universiti Utara Malaysia, Malaysia \\ *Corresponding author.Email: adiekola@gmail.com
}

\begin{abstract}
Inconsistencies in the findings of past literature on the relationship between quality management practices and sustainable performance have provoked the essence of this study. This has prompted further evaluation of the effects of critical quality management variables to explain the relationships' nature better. Therefore, this study investigates the mediating effect of organizational excellence on the relationships between total quality management practices and sustainability performance. This study's quality management practices are human resources management, service design, information and analysis, continuous process improvement, benchmarking, quality assurance and management leadership, and their respective relationship with sustainable performance while being mediated by organizational excellence. The developed framework from this study can be employed by policy and decision-makers. Also, the managers aiming to achieve sustainability and excellence can consider the importance of this model when implementing any practice in the future.
\end{abstract}

Keywords: total quality management, sustainable performance, organizational excellence.

\section{INTRODUCTION}

Achieving organizational excellence is the main objective of innovative and quality management im-plementation. According to Oakland Consultation (2005), business excellence practically supports the organization in accepting and dealing with change. Managers require sustainable excellence to have a clear mission to lead their team and achieve goals for the stakeholders and customers of the organization. According to Antony and Bhattacharyya (2010), excellence is the highest and most outstanding performance; therefore, any organization must pay attention to it. Nowadays, in achieving a high performance record, many organizations must struggle first to achieve organizational excellence to stand out from other competitors in the market. However, many organizations have failed to achieve excellence due to a lack of knowledge regarding business excellence processes and concepts (Dahlgaard 2003).

This study, therefore, intends to comprehensively investigate the relationship between quality manage-ment practices such as human resources management, management leadership, service design, continuous process improvement, information and analysis, benchmarking, and quality assurance with sustainable performance and organizational excellence. The need for more studies on the association between sustainable performance and Total Quality Management (TQM) with a review on the current system of qualities of factory like present manufacturing procurements and procedures and application of management and standards in line with environmental, economic, and social development are the issues that prompted the purpose of this study. 


\section{DISCUSSION}

\subsection{Total quality management practices}

According to Agus and Hassan (2011), TQM pro-vides a set of practices that encompasses meeting customer expectations, increased employee involvement and teamwork, work reduction, long-ranged thinking, competitive benchmarking, constant result measurement, continuous improvement, team-based problems solving, and good intimacy with suppliers.

Furthermore, Brah et al. (2000), who use the perceptions, experience, and criteria of a range of total quality practitioners, state that the critical factors of implementing TQM are employee empowerment, service design, process improvement, employee involvement, supplier quality management, top management support, employee training, and customer focus. The study suggests that TQM and its implementation apply to the service sector and are associated with better business performance. In another vein, Brah et al. (2000) identify the critical internal factors to successfully implement TQM: quality focus, customer focus, information and analysis, top management leadership, corporate planning, process focus, and human resources focus. The study shows that effective implementation of these practices leads to performance improvement of an organization.

Based on this information from TQM literature, both empirical and conceptual studies and models of quality award (Izvercian et al. 2014), the core elements of TQM are identified in this study.

\subsection{Sustainable performance}

In recent times worldwide, sustainability is gaining and getting prominence among stakeholders and or-ganizations (Caiado et al. 2018). Thus, sustainable performance is achieved when a firm and company build continuous values for its shareholders and stakeholders while abiding with the environmental requirement (Brent \& La- buschagne 2004). The sus-tainable value of a firm has few essential parts, which are: making the shareholders and customer happy and, more importantly, performing well for the society and environment (Hassan et al. 2018). Dunphy (2011) adds that sustainable consists of actions that extend the socially useful life of the or-ganization, enhance the ability to maintain and renew viability of the biosphere and protect all living species, enhance the ability of society to maintain itself and solve its major problem, and maintain a decent of welfare, participation, and personal freedom for present and future generations of humanity.

Sustainability involves creating and maintaining the conditions in which nature and humans can co-exist in productive harmony that allows achieving economic, social, and other current and future generations (Cherrafi et al. 2016). In the manufacturing industries, sustainability aims to create manufactured products that use processes and practices that increase profit, reduce negative environmental effects, conserve energy and natural resources, and are safe for communities, employees, and consumers.

Therefore, the proposed framework applied to assess sustainable performance in this study is classified into three measurements as supported by previous studies on sustainable performance. The measurements are social, economic, and environmental sustainability. Therefore, to embrace sustainability, these three measurements of sustainable performance are essential to operate a successful business for the present and future (Eweje 2011).

\subsection{Organizational Excellence}

The word "excellence" is used to refer to the evalua-tion of the highest rank. It is not easy to recognize when the state of excellence is attained if what excellence is entailed is not known (Dahlgaard-Park 2009). The term "excellence" is used frequently in organizations and businesses; however, it similarly implies distinction, but organizational excellence is ap-plied more in the public sector 
while business excellence is used in the private sector (McAdam 2000).

Al Shobaki \& Naser (2016) stipulate that excellence is a concept that is indivisible, comprehensive, and holistic because there is no difference in any organization in a particular sector from others. While performance is broken down in another area, tangles and equilibrium marked by two excellence characteristics in the various sectors of organizations that comprise the two measurements of modern management parts: the real management that seeks to achieve excellence and other things that come from management such as events, decisions, and systems characterized by excellence are adopted. The study opines that excellence is created to identify organizational capability to achieve performance excellence, quality growth awareness, superior and quality performance within a competitive model. Therefore, organizational excellence is a set of practices and strategies, not just an ultimate objective to achieve medals and prizes such as achieving sus-tainability performance through innovation.

Sustainable performance and organizational excel-lence are the most critical measurement indicators for the advancement, success, achievement, development, and competitiveness of any organization (Akanmu et al. 2020). These indicators are inter-related, yet each one can lead to another; however, sustainable performance is achieved by practicing organizational excellence that comprises innovation. According to European Foundation Quality Management (EFQM), organizations with 60 percent perfor-mance and above are considered excellent organiza-tions. Excellence is considered in the current excel-lence models as outstanding performance level (An-tony \& Bhattacharyya 2010). The basic questions now are: how can organizations pursue, sustain busi-ness excellence, and achieve competitive advantage in business performance (Dahlgaard \& Dahlgaard-Park 2009).

Therefore, this preliminary study examines the development process of the hypoth- eses between the relationships as discussed in the following section:

\subsection{The mediating effect of organizational excellence between management leadership and sustainable performance}

Excellence, when connected to the implementation of TQM, takes different pattern in several aspects such as continuous improvement in terms of processes and facts, development and innovation of partnership, learning and public responsibility, orientation to results and customers, and leadership management with the coherence of objectives (Mele \& Colurcio 2006). In furtherance, Sharma and Kodali (2008), on implementing TQM elements to achieve excellence, develop a model for implementing sustainable manufacturing excellence from leadership. The study reveals that the framework is categorized into three, namely: consultant-based, academic or researchbased, or award-based. An organization can achieve an excellent position when it has the capability to lead to optimum value and sustainable performance concerning competitors. McAdam (2000) states that a key stage on the journey of management leadership is organizational excellence. Thus, the hypothesis below is proposed:

$\mathrm{H} 1$ : the relationship between management leadership and sustainable performance is mediated by organi-zational excellence.

\subsection{The mediating effect of organizational excellence between benchmarking and sustainable performance}

Recently, the emergence of organizational excellence has a similar interpretation to business excellence except that it is more applicable in public sector organizations (McAdam 2000). The main objective of all organizations is excellence - excellence resulting from the creative and innovative implementation of strategy such as benchmarking and its path to competitive advantage and success (Vora 2002). Benchmarking is one of the main factors that promote organi- 
zations to achieve business excellence through TQM (Mele \& Colurcio 2006).

In contribution, Kanji (1998) studies the measurement and individual features of excellence features while measuring stakeholder satisfaction to obtain a detailed analysis of the sustainable performance. Additionally, the goal of an organization is to have TQM and adopt its managerial method through benchmarking towards achieving sustainable performance (McAdam et al. 1998). Therefore, the study proposed the following hypothesis:

$\mathrm{H} 2$ : the relationship between benchmarking and sus-tainable performance is mediated by organizational excellence.

\subsection{The mediating effect of organizational} excellence between continuous process improvement and sustainable performance

TQM is a problem-solving methodology and an or-ganization-wide philosophy that focuses on continu-ous and systematic improvement of process quality of product and services. While, according to Adebanjo (2001), quality improvement and business excellence complement each other. Most excellence models such as EFQM comprises continuous process improvement are in accordance with the concepts of TQM as a holistic approach, and some of the quality models have been moved to excellence, such as Environmental Quality Act (EQA), now referred to as EFQM excellence award (Adebanjo 2001).

Considering the public sector, the difference between TQM and excellence is most apparent where there is an attempt to include the concept of TQM into the public sector, but there is no proof that it was successful (Cairncross 2000). From this discussion, it is safe to conclude that quality management through continuous improvement can enhance an organization to achieve excellence (Hassan et al. 2007, Lee 2002). In another vein, excellence practices such as continuous process improvement and models according to TQM principles can lead to a high sus- tainable performance level (Ioncia \& Baleanu 2010). Therefore, the study proposed the following hypothesis:

H3: the relationship between continuous process im-provement and sustainable performance is mediated by organizational excellence.

\subsection{The mediating effect of organizational excellence between service design and sustainable performance}

Organizations are supported in integrating and auto-mating corporate cross-functions such as finance, project management, distribution, inventory, and procurement and improving business performance through service design. The existing system lacks integration of different functions of the organization where the core system, such as the service design, requires all components to work together to acquire excellent performance (Tarn et al. 2002). Also, using Six Sigma and service design enhance implementation of best business practice to accomplish excellence in business processes (Rao 2008). Moreover, organizational excellence is considered a practice that supports the organization to achieve excellence to grow (Atta-far et al. 2012). Masli et al. (2010) stipulate that to generate the best results, there must be a demonstration of excellence in information technology. Due to the inconsistency in the results between service design and sustainable performance, organizational excellence is introduced as the mechanism to mediate the relationship. Therefore, the study proposed the following hypothesis:

H4: the relationship between service design and sus-tainable performance is mediated by organizational excellence.

\subsection{The mediating effect of organizational excellence between human resources management and sustainable performance}

Recently, some scholars just discuss the effect of hu-man resource management on sus- 
tainable perfor-mance. The next question is, how does human re-sources management enhance performance, and what/how does this effect be explained. Therefore, these questions are answered with the emergence of organizational excellence. Therefore, it is proposed in this study to serve as a mediator between sustainable performance and human resources management. As earlier mentioned, the association between organizational excellence and human resources management and the relationship between organizational excellence and sustainable performance at another end were hypothesized to have significant relationships as last literature approved the association between the variables. Additionally, Lau and Zhang (2006) say that the indirect human resources management-sustainable performance is more prominent than the direct relationship. From another perspective, the association between human resources management and sustainable performance is not direct; other elements can affect the relationship (Vij \& Bedi 2012).

Other mediators between human resources management and sustainable performance which may explain the relationship such as organizational activities was opined by Lumpkin and Dess (1996). According to Harms (2013), only past studies investigate the mediating effect of the human resources management-performance relationship. The findings reveal partial mediation, this indicates a need for a mediator to explain the relationship better. Due to this fact, this study hypothesized to test the following:

H5: the relationship between human resources man-agement and sustainable performance is mediated by organizational excellence.

\subsection{The mediating effect of organizational excellence between quality assurance and sustainable performance}

Basically, quality assurance is the sustenance of a re-quired level of product quality and services by attending every production and delivery stage. In other words, quality assurance comprises systematic management and assessment procedures to achieve quality results. This study employs planning, design, analysis, and production, and post-production and delivery as the measure to examine quality assurance (Cukier et al. 2012). Quality assurance is measured by the rate at which organizational excellence is being followed. According to Chervinski (2014), it is an attribute of the functional significance, social and regulatory relationships of which are depended on the capacity to reflecting the maximum organizational excellence. The organization's concern to protect quality affects the high demands of compelling organizational excellence on production and product end-of-life processes. Thus, the study hypothesized the following:

H6: the relationship between quality assurance and sustainable performance is mediated by organiza-tional excellence paper.

\subsection{The mediating effect of organizational excellence between information and analysis and sustainable performance}

The TQM key elements include information and analysis, a strong customer focus, a well-executed approach to process management, strong emphases on design quality, and extensive employee development and participation (Hayes et al. 2001). Contrary to the traditional manufacturing environment, in which the management fully controls information, TQM theory calls for a continuous flow of information to the employees who are actually per-forming the work to achieve sustainability within the organization. There are two forms to the recommended information: the process information for source identification of defects and the consequence of the improvement activities monitoring (Reeve 1990). Provision of process information encourages closer coordination and communication between workgroups, facilitates problem correction and identification between workgroups, and allows more rapid cross-functional problem solving and smoother production flow. 
Information on plans and strategic priorities must be broadly communicated through the organization. By communicating and analyzing information on strategic plans and priorities to workers, organizations can help ensure that the chosen project contributes to broader business objectives. Moreover, the role of TQM in achieving strategic goals can be explicit by distributing quality strategies, plans, and goals to board members and executives and incorporating this information into the information and analysis process to achieve excellence. Thus, the hypothesis proposed is below:

H7: the relationship between information and analysis and sustainable performance is mediated by organizational excellence.

With the above hypotheses developed, Figure 1 below shows the conceptual framework connecting the TQM practices, organizational excellence, and sustainable performance together and their relationships to be tested:

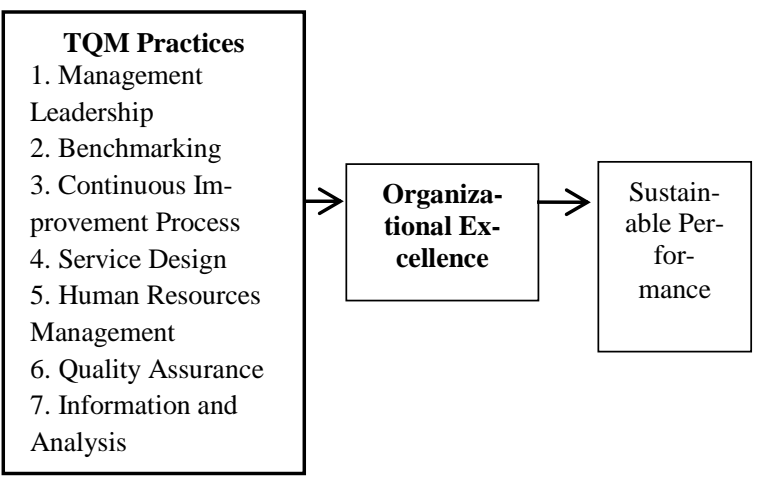

Figure 1. Conceptual Model of TQM practices, Organizational Excellence and Sustainable Performance.

\section{CONCLUSION}

The importance of TQM practices in many industries is demonstrated in this study. It contributes theoretically to the TQM literature by reexamining unresolved matters on the relationship between the TQM elements and sustainable performance. The inconsistencies in previous research on the effect of quality management practices on sustainability have called for further investigation and discussion. Therefore, this study contributes to the existing literature by integrating business excellence as the innovative practice and strategy to the theoretical framework to better explain the construct variance of sustainable performance. The outcomes of the mediating effect of organizational excellence between TQM elements and sustainable performance shall be tested to examine the critical roles of excellence models. The proposed framework can create more awareness among managers, practitioners, decisionand policy-makers on the importance of excellence models to enhance sustainability and competitive advantage through hypotheses. Therefore, there is a need to increase this awareness about the essential role of business excellence.

\section{REFERENCES}

Adebanjo, D. 2001. TQM and business excellence: is there really a conflict?. Measuring Business Excellence 5(3): 37-40.

Agus, A. \& Hassan, Z. 2011. Enhancing Production Performance and Customer Performance through Total Quality Management (TQM): Strategies for Competitive Advantage. Procedia - Social and Behavioral Sciences 24: 1650-1662.

Akanmu, M.D. Hassan, M.G. \& Bahaudin, A.Y.B. 2020. A preliminary analysis modeling of the relationship between quality management practices and sustainable performance. Quality Management Journal 27(1): 37-61.

Al Shobaki, M.J. \& Abu-Naser, S.S. 2016. The Dimensions of Organizational Excellence in the Palestinian Higher Education Institutions from the Perspective of the Students. Information Technology \& Electrical Engineering (6)2: 47-58.

Antony, J.P. \& Bhattacharyya, S. 2010. Measuring organizational performance and organizational excellence of SMEs - Part 2: an empirical study on SMEs in India. Measuring Business Excellence 14(3): 42-52.

Brah, S.A. Wong, J.L. \& Rao, B.M. 2000. TQM and business performance in the service sector: a Singapore study. International Journal of Operations \& Production Management 20(11): 1293-1312.

Brent, A.C. \& Labuschagne, C. 2004. Sustainable Life Cycle Management: Indicators to assess the sustainability of engineering projects and technologies. Paper presented at the International Engineering Management Conference 11: 3-15.

Caiado, R.G.G. Quelhas, O.L.G. Nascimento, D.L.M. Anholon, R. \& Leal Filho, W. 2018. Measurement of sustainability performance in Brazilian organi- 
zations. International Journal of Sustainable Development \& World Ecology 25(4): 312-326.

Caircross, J. 2000. Modernizing government through excellence. UK Excellence: 32-33.

Cherrafi, A. Elfezazi, S. Chiarini, A. Mokhlis, A. \& Benhida, K. 2016. The integration of lean manufacturing, Six Sigma and sustainability: A literature review and future research directions for developing a specific model. Journal of Cleaner Production 139: 828-846.

Chervinski, A. 2014. Ecological Evaluation of Economic Evaluation of Environmental Quality. Procedia Economics and Finance 8(14): 150-156.

Cukier, W. Barkel, E. Vaughan, T. \& Gekas, G. 2012. Quality assurance in Canadian police services. The TQM Journal 24(4): 295-309.

Dahlgaard, J. 2003. QMOD - The management challenge for the new millennium. European Quality 10(3): 10-14

Dahlgaard-Park, S.M. 2009. Decoding the code of excellence - for achieving sustainable excellence. International Journal of Quality and Service Sciences 1(1): 5-28.

Dunphy, D. 2011. Chapter 1 Conceptualizing Sustainability: The Business Opportunity, Gabriel Eweje, Martin Perry, in (ed.) Business and Sustainability: Concepts, Strategies and Changes (Critical Studies on Corporate Responsibility, Governance and Sustainability (3): Emerald Group Publishing Limited.

Eweje, G. 2011. Chapter 7 Managerial Perceptions of Sustainability, Gabriel Eweje, Martin Perry, in (ed.) Business and Sustainability: Concepts, Strategies and Changes (Critical Studies on Corporate Responsibility, Governance and Sustainability (3): Emerald Group Publishing Limited.

Harms, R. 2013. From Entrepreneurial Orientation to Performance: inside the black box of corporate entrepreneurship. Corporate Entrepreneurship 16(4): 357-432.

Hassan, M.G. Akanmu, M.D. \& Yusoff R. Z. 2018. Technological Integration and Sustainable Performance in Manufacturing Firms. International Journal of Technology 9(8): 1639-1650.

Hayes, D.C. Hunton, J.E. \& Reck, J.L. 2001. Market reaction to ERP implementation announcements. Journal of Information System 15(1): 3-18.

Izvercian, M. Radu, A. Ivascu, L. \& Ardelean, B.O. 2014. The Impact of Human Resources and Total Quality Management on the Enterprise. Procedia - Social and Behavioral Sciences 124: 27-33.

Kanji, G.K. 1998. Measurement of business excellence. Total Quality Management 9(7): 633-643.

Lau, K.H. \& Zhang, J. 2006. Drivers and obstacles of outsourcing practices in China. International Journal of Physical Distribution \& Logistics Management 36(10): 776-792.

Lumpkin, G.T. \& Dess, G.G. 1996. Clarifying the entrepreneurial orientation (EO) construct and link- ing it to performance. Academy of Management Review 21(1): 135-172.

Masli, A. Richardson, V.J. Sanchez, J.M. \& Smith, R.E. 2011. Returns to IT excellence: Evidence from financial performance around information technology excellence awards. International Journal of Accounting Information Systems 12(3): 189-205.

McAdam, R. 2000. Quality models in an SME context. International Journal of Quality and Reliability Management 17: 305-323.

McAdam, R. Armstrong, G. \& Kelly, B. 1998. Investigation of the relationship between total quality and innovation: a research study involving small organizations. European Journal of Innovation Management 1(3): 39-47.

Mele, C. \& Colurcio, M. 2006. The evolving path of TQM: towards business excellence and stakeholder value. International Journal of Quality \& Reliability Management 23(5): 464-489.

Oakland Consultation, 2005. Leadership and policy deployment-the backbone of TQM. John Oaklan Paper for TQM \& Business Excellence: 517-534.

Rao, P.H. 2008. Greening the supply chain: A guide for Asian managers. New Delhi: SAGE Publications.

Reeve, J.M. 1990. The impact of variation on operating system performance. Performance Excellence in Manufacturing and Service Organizations, edited by P BB Turney. Sarasota, Fla.: American Accounting Association.

Sharma, M. \& Kodali, R. 2008. TQM implementation elements for manufacturing excellence. The TQM Magazine 20(6): 599-621.

Tarn, M. Yen, D. \& Beaumont, M. 2002. Exploring the rationales for ERP \& SCM integration. Industrial Management \& Data Systems 102(1): 26-34.

Vij, S. \& Bedi, H.S. 2012. Relationship between entrepreneurial orientation and business performance: A review of literature. The IUP Journal of Business Strategy 21 (3): 17-31.

Vora, M.K. 2002. Business excellence through quality management. Total Quality Management 13(8): $1151-1159$. 